\title{
Towards a Better English Classroom: Implementing Effective Classroom Management Strategies
}

\author{
Sana' Ababneh ${ }^{1, *}$ \\ ${ }^{1}$ Al-huson University College, Department of Basic Science, Al-Balqa'a Applied University, \\ Irbid, Jordan \\ *Correspondence: Al-huson University College, Department of Basic Science, Al-Balqa'a \\ Applied University, Irbid, Jordan \\ E-mail: sanabneh@yahoo.com
}

Received: October 25, 2012 Accepted: November 25, 2012 Published: December 19, 2012

doi:10.5296/ije.v4i4.2563 URL: http://dx.doi.org/10.5296/ije.v4i4.2563

\begin{abstract}
This paper investigated to what extent EFL staff at Al-Balqa'a Applied University implement appropriate classroom management elements from the perspective of their students'. The results showed that students believed that their English teaching staff at the university displayed good implementation of classroom elements under study. Factors like gender and academic major at the university did not have a significant influence on students' responses. Findings may be useful to English teachers and teacher educators in developing a self-judgment process in order to revise their practice to enhance the educational experience. This is especially true for novice teachers who need advice in managing their classes. Furthermore, the study sheds light on the importance of giving the students' a role in assessing their teachers and to pinpoint the positive and the negative points in their classrooms. This could create a better teaching atmosphere which of course could lead to a successful learner.
\end{abstract}

Keywords: classroom management; strategies; English; teaching; English as a foreign language 


\section{Introduction}

EFL classroom as well as other classrooms requires certain elements that are necessary to make it useful and interesting for both the teacher and the learners. The problem with EFL learners lies in the fact that they have little chance to use the target language in daily life thus, they have to depend entirely on classroom activities as for the majority of them, the classroom is the only environment in which they can practice communicating in the target language. So EFL teachers must bear it in mind that neither control nor discipline but setting an appropriate climate for learning in their class is their most important task for classroom management (Yi, n.d.: 130). Richards, Platt\& Platt (1992:52) define classroom management in language teaching as:

"the ways in which student behavior, movement, interaction, etc., during a class is organized and controlled by the teacher to enable teaching to take place most effectively. Class room management includes procedures for grouping students for different types of classroom activities, use of LESSON PLANS, handling of equipment, aids, etc., and the direction and management of student behavior and activity."

Brown (2001:192-4) classified classroom management elements into the physical environment of the classroom such as the sight, sound and comfort; the seating arrangements; the use of the board and the equipments needed in the class. And those elements which are related to the teacher such as his/her voice and body language. So EFL teachers should master adequate class room management strategies that will help them control the class and make their students enjoy it rather than hate it or consider it as a heavy burden.

Studies in the field show that teachers who adopt a relationship-building approach to classroom management by focusing on developing the whole person are more likely to help students develop positive, socially-appropriate behaviors. Bender (2003) concluded that the effective relationship between the teacher and the students is not determined by the good nature of the teacher rather to his/her use of appropriate behaviors, strategies, and fundamental attitudes. Furthermore, this perspective is supported by research suggesting that teachers who develop such relationships experience fewer classroom behavior problems and better academic performance by their students (Decker, Dona, \& Christenson, 2007; Marzano, Marzano, \& Pickering, 2003; Hall \& Hall, 2003; Rogers \& Renard, 1999).

Learning English definitely brings benefit to its learner as English has become an international language and it is increasingly used as a tool of interaction between people from various nationalities. According to Brown (2001: 118), "one half of the one billion English speakers of the world learned English as a second or foreign language." From this fact stems the importance of learning English and the importance of using effective strategies that facilitate the learning of English as it opens new avenues to its learners in order to have better job opportunities as well as better chances in keeping up with what is new in their field of specialty as English has become "a tool for international communication in transportation, commerce, banking, tourism, technology, diplomacy, and scientific research.”(Brown, 2001: 118) 
Nevertheless, Jordanian EFL learners have negative feelings towards learning English and they consider it as the most difficult subject at school although Jordan is a country where many subjects at the university level are taught in English such as medicine, technology and engineering (Carkin, 2005).

From the above discussion stems the importance of creating a positive atmosphere for learning English through creating a new generation of English teachers who enjoy a variety of classroom management techniques and strategies that motivate the students and encourage them to be better learners.

\section{Methodology}

\subsection{Questions of the Study}

The purpose of this study was to identify the opinions of Al-Balqa'a Applied University students' about how effective classroom management components are implemented by the English language teaching staff at Al- Huson University College - one of the colleges of Al-Balqa'a Applied University. The following are the specific questions of the study:

1) To what extent are effective classroom management components are implemented by the English language teaching staff from the perspective of their students?

2) Are there significant differences between students' evaluation of the degree of implementing effective classroom management components by the English language teaching staff due the difference in their gender?

3) Are there significant differences between students' evaluation of the degree of implementing effective classroom management components by the English language teaching staff due the difference in the academic major of the students?

\subsection{Significance of the Study}

The significance of this study stems from giving the university students at Al- Balqa'a Applied University an opportunity to evaluate the extent of which their English language teaching staff enjoy the appropriate use of the effective classroom management components. As most of the students have negative attitudes towards learning English, and a great number of them are poor achievers too. Thus the researcher tried to shed light on their needs as teachers could play a significant role in being facilitators rather than dictators (Wang, \& Kania- Gosche, 2011:23). In the same vein, Rogers (1969) defined the aim of education as the facilitation of learning (pp.104-105). And since classroom management is considered the core stone of teaching in all education levels, teachers are invited to implement the appropriate class room strategies and techniques in dealing with students in and outside the classroom, planning for the lesson and taken into account the behavior of students in a particular classroom climate and meeting the needs of the students to organize and arrange classroom environment and to keep it convenient for students so that he/she achieves the desired educational objectives (Al- Momani, Allouh and Al-humran,2012:142). Moreover, 
the study investigates some other factors that might affect students' assessment such as the difference in their gender and their academic major.

\subsection{Study population}

The study population consisted of all students of Al- Huson University College -AlBalqa Applied University, Jordan. Both male and female students who are enrolled in the study in the bachelor degree program in the second semester of the academic year 2011/2012.

\subsection{Study Sample}

The sample of the present study consisted of 83 students who were randomly chosen from the study population. Those subjects were both male and female students who were registered in the English courses $(101,102,099)$ and from different sections which are of course taught by different instructors so that their evaluation could be more representative. The subjects of the study have different majors too. Their majors were: Engineering, MIS, Accounting, Vocational education, and Computer science.

Table (1) below shows the distribution of the subjects of the study according to their gender.

Table 1: Distributions of the Subjects according to their gender

\begin{tabular}{llllll}
\hline & & Frequency & Percent & Valid Percent & \multicolumn{1}{c}{$\begin{array}{l}\text { Cumulative } \\
\text { Percent }\end{array}$} \\
\hline Valid & male & 38 & 45.8 & 45.8 & 45.8 \\
& female & 45 & 54.2 & 54.2 & 100.0 \\
& Total & 83 & 100.0 & 100.0 & \\
\hline
\end{tabular}

Instruments of the Study

The researcher used a Likert- scale questionnaire that uses five degrees ranging from one to five. One refers to strongly disagree and five to strongly agree. This questionnaire was adopted from (Al- Momani, Allouh and Al-humran, 2012:142).

The questionnaire consisted of thirty-four items distributed over four domains. The first included aspects related to students' behavior and it consisted of six items. The second was about aspects concerning classroom atmosphere and students' needs, twelve items were included in this domain. The third catered for aspects related to lesson- planning and educational tasks and it had twelve items too. The fourth looked for aspects related to classroom organization and preparing the appropriate environment for teaching and it consisted of five items.

\subsection{Procedures of the study}

The instrument of the study was applied during the last week of the second semester of the academic year 2011/2012. The researcher distributed the questionnaire to the subjects of the study. The researcher clarified the objectives of the study and explained the proper way to answer the paragraphs of the questionnaire and translated the items to Arabic when necessary 
to guarantee the proper comprehension of each statement of the questionnaire.

\section{Analysis}

Subjects of the study were asked to evaluate the extent of which their English language teachers implement the appropriate classroom management components by responding to the thirty-four questionnaire statements which were divided into four domains as mentioned earlier.

Table (2) below shows the mean scores and the standard deviations of students' responses to each statement of the questionnaire.

Table 2: Mean scores and Standard Deviations of students' responses on the questionnaire statements

Std.

\begin{tabular}{|c|c|c|c|c|c|}
\hline Questionnaire Statements & $\mathrm{N}$ & Min & $\operatorname{Max}$ & Mean & deviation \\
\hline 1.Shows desirable attitude through praising & 83 & 1.00 & 5.00 & 4.07 & .728 \\
\hline 2.Treats students strictly and fairly & 83 & 1.00 & 5.00 & 4.10 & .897 \\
\hline 3. Deals with misbehaving students appropriately & 83 & 2.00 & 5.00 & 3.90 & .864 \\
\hline 4. Carefully observes uneven behavior & 83 & 1.00 & 5.00 & 3.89 & .975 \\
\hline 5. Avoids treating students harshly & 83 & 1.00 & 5.00 & 3.77 & 1.06 \\
\hline 6. Does not ignore uneven behavior & 83 & 1.00 & 5.00 & 3.90 & 1.13 \\
\hline 7. Considers the level of attention of students & 83 & 1.00 & 5.00 & 4.06 & .96 \\
\hline 8. Providers friendly atmosphere in classroom & 83 & 1.00 & 5.00 & 4.16 & 1.02 \\
\hline 9. Encourages good performance & 83 & 1.00 & 5.00 & 4.14 & .89 \\
\hline $\begin{array}{l}\text { 10. Provides different exercises that suits different } \\
\text { individuals }\end{array}$ & 83 & 1.00 & 5.00 & 3.50 & 1.11 \\
\hline $\begin{array}{l}\text { 11. Encourages students to express their thoughts and } \\
\text { ideas }\end{array}$ & 83 & 1.00 & 5.00 & 4.04 & .961 \\
\hline 12. Considers the interests of students & 83 & 1.00 & 5.00 & 3.46 & 1.03 \\
\hline 13. Considers the needs of slow learners & 83 & 1.00 & 5.00 & 3.30 & 1.14 \\
\hline 14. Develops friendly relationships with students & 83 & 1.00 & 5.00 & 3.57 & 1.12 \\
\hline 15. Considers the needs of advanced students & 83 & 1.00 & 5.00 & 3.80 & 1.06 \\
\hline 16. Gives assignments that suit the level of students & 83 & 1.00 & 5.00 & 3.65 & 1.08 \\
\hline 17. Organizes group discussions to solve class problems & 83 & 1.00 & 5.00 & 3.91 & 1.16 \\
\hline $\begin{array}{l}\text { 18. Prepares the necessary educational tasks prior to } \\
\text { class }\end{array}$ & 83 & 1.00 & 5.00 & 3.90 & .99 \\
\hline $\begin{array}{l}\text { 19. Distribute responsibilities among students to do } \\
\text { exercises that are included in the curriculum or extra } \\
\text { exercises }\end{array}$ & 83 & 1.00 & 5.00 & 3.72 & 1.09 \\
\hline 20. Runs lesson time effectively & 83 & 1.00 & 5.00 & 4.34 & .916 \\
\hline 21. Explains ambiguous issues in the lesson & 83 & 1.00 & 5.00 & 4.34 & .875 \\
\hline
\end{tabular}


22. Presents the lesson contents in a systematic flow

23. Uses various educational methods

24. Uses various teaching strategies

25. Provides clear instructions for asked assignments

26. States the lesson objectives before teaching

27. Uses appropriate speed when explain a lesson

28. Assessing students during the learning process

29. Uses suitable and clear language while teaching

$\begin{array}{lllll}83 & 2.00 & 5.00 & 4.30 & .837 \\ 83 & 1.00 & 5.00 & 3.72 & 1.12 \\ 83 & 1.00 & 5.00 & 3.50 & 1.16 \\ 83 & 1.00 & 5.00 & 3.79 & 1.13 \\ 83 & 1.00 & 5.00 & 4.12 & 1.09 \\ 83 & 1.00 & 5.00 & 4.07 & .823 \\ 83 & 2.00 & 5.00 & 3.72 & 1.02 \\ 82 & 1.00 & 5.00 & 4.21 & 1.00 \\ 83 & 1.00 & 5.00 & 3.63 & 1.15 \\ 83 & 1.00 & 5.00 & 3.59 & 1.16 \\ 83 & 1.00 & 5.00 & 3.56 & 1.26 \\ 83 & 1.00 & 5.00 & 3.84 & 1.19 \\ 83 & 1.00 & 5.00 & 4.10 & 1.14 \\ 82 & & & & \end{array}$

The thirty-four statements included in the above questionnaire were divided into four domains as mentioned earlier. Table three below shows the means and the standard deviations of the subjects' responses on the questionnaire statements according to the domains.

Table 3: Mean scores and Standard Deviations of Students' Responses According to the Questionnaire Domains

\begin{tabular}{|c|c|c|c|c|c|}
\hline & $\mathrm{N}$ & Min & Max & Mean & $\begin{array}{c}\text { Std. } \\
\text { Deviation }\end{array}$ \\
\hline Domain 1 & 83 & 1.33 & 5.00 & 3.94 & .584 \\
\hline Domain2 & 83 & 2.18 & 5.00 & 3.78 & .633 \\
\hline Domain3 & 83 & 2.50 & 5.00 & 3.97 & .643 \\
\hline Domain4 & 83 & 1.60 & 5.00 & 3.74 & .905 \\
\hline Valid N (listwise) & 83 & & & & \\
\hline
\end{tabular}

N: Number of students.

Domain 1: Aspects related to students' behavior and it had six statements.

Domain 2: Aspects concerning classroom atmosphere and students' need.

Domain 3: Aspects related to planning for a lesson and teaching tasks.

Domain 4: Aspects related to the organization and preparation of classroom environment.

\section{Findings}

Results related to the first question: To what extent are effective classroom 
management components implemented by the English language teaching staff from the perspective of their students?

From Table (2) one can tell that the overall mean of the subjects' responses to the statements of the questionnaire is (3.86). This means that the scale items got positive evaluation from students. To be more specified if one looks at table (3) which illustrates the responses according to the four domains, he could see that the overall mean is (3.85). Thus it is clear that most of the responses are classified as positive as they are in the scale of agreement to the statements which they were asked about.

Results related to the second question: Are there significant differences between students' evaluation of the degree of implementing effective classroom management components by the English language teaching staff due the difference in their gender? To answer this question the researcher did a t-test of equality to the mean scores of the subjects' responses on the questionnaire statements according to their gender. Table (4) shows the statistics and the results of T-test.

Table 4: Means and Standard Deviations Students' Responses on the Questionnaire According to Gender

\begin{tabular}{|c|c|c|c|c|c|}
\hline & \multirow[b]{2}{*}{ Gender } & \multicolumn{4}{|c|}{ Std. } \\
\hline & & $\mathrm{N}$ & Mean & Deviation & Std. Error \\
\hline \multirow[t]{2}{*}{ Domain 1} & Male & 37 & 3.84 & .604 & .099 \\
\hline & Female & 45 & 4.01 & .565 & .084 \\
\hline \multirow[t]{2}{*}{ Domain 2} & Male & 37 & 3.69 & .649 & .106 \\
\hline & Female & 45 & 3.84 & .615 & .091 \\
\hline \multirow[t]{2}{*}{ Domain 3} & Male & 37 & 3.85 & .607 & .099 \\
\hline & Female & 45 & 4.06 & .660 & .098 \\
\hline \multirow[t]{2}{*}{ Domain 4} & Male & 37 & 3.74 & .854 & .140 \\
\hline & Female & 45 & 3.73 & .956 & .142 \\
\hline
\end{tabular}

From Table (4) it could be said that the total mean score of female respondents is (15.64) which is somehow more than the mean score of male respondents which is (15.12). To investigate if these differences are statistically significant at $\alpha=0.05$, the researcher did a t-test of equality between the subjects responses on the four domains. Table (5) shows this. 


\section{Macrothink}

International Journal of Education

ISSN 1948-5476

2012, Vol. 4, No. 4

Table 5: Mean scores and T- test of Students' Responses on the Questionnaire According to Gender

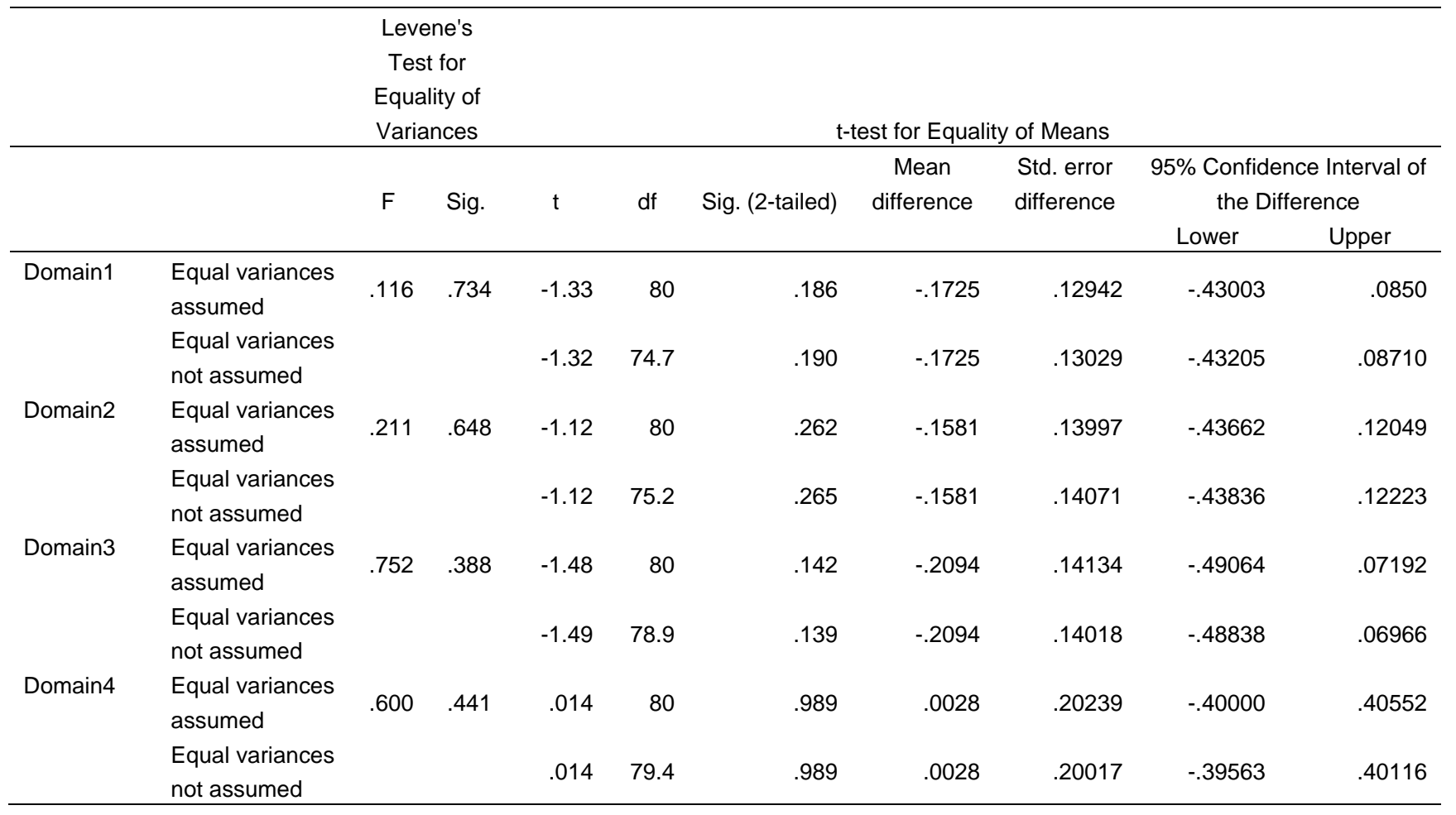

Table (5) shows that there are no statistically significant differences at $\alpha=0.05$ between male and female responses on the four domains. Thus gender has no influence on students' responses.

Results related to the third question: Are there any significant differences between students' evaluation of the degree of implementing effective classroom management components by their English language teaching staff due the difference in the academic major?

To see answer this question, the researcher did a t-test of covariance between the students' responses on the questionnaire statements. No significant differences were found between students' responses that could be attributed to the different academic majors of the subjects who participated in the study. Table (6) showed this result.

Table 6: Results of Anova Analysis of the Means of the Students' Responses on the Questionnaire

\begin{tabular}{|c|c|c|c|c|c|c|}
\hline & & $\begin{array}{l}\text { Sum of } \\
\text { Squares }\end{array}$ & $d f$ & $\begin{array}{l}\text { Mean } \\
\text { Square }\end{array}$ & $\mathrm{F}$ & Sig. \\
\hline \multirow[t]{3}{*}{ Domain 1} & $\begin{array}{l}\text { Between } \\
\text { Groups }\end{array}$ & .75 & 4 & .188 & \multirow[t]{3}{*}{.539} & \multirow[t]{3}{*}{.708} \\
\hline & $\begin{array}{l}\text { Within } \\
\text { Groups }\end{array}$ & 27.21 & 78 & .349 & & \\
\hline & Total & 27.96 & 82 & & & \\
\hline \multirow[t]{2}{*}{ Domain 2} & $\begin{array}{l}\text { Between } \\
\text { Groups }\end{array}$ & .27 & 4 & .069 & \multirow[t]{2}{*}{.164} & \multirow[t]{2}{*}{.956} \\
\hline & Within & 32.64 & 78 & .418 & & \\
\hline
\end{tabular}




\begin{tabular}{|c|c|c|c|c|c|c|}
\hline & Groups & & & & \multirow[b]{3}{*}{.734} & \multirow[b]{3}{*}{.571} \\
\hline \multirow[b]{2}{*}{ Domain 3} & Total & 32.91 & 82 & & & \\
\hline & $\begin{array}{l}\text { Between } \\
\text { Groups }\end{array}$ & 1.23 & 4 & .308 & & \\
\hline \multirow{5}{*}{ Domain 4} & $\begin{array}{l}\text { Within } \\
\text { Groups }\end{array}$ & 32.71 & 78 & .419 & \multirow{5}{*}{.291} & \multirow{5}{*}{.883} \\
\hline & Total & 33.94 & 82 & & & \\
\hline & $\begin{array}{l}\text { Between } \\
\text { Groups }\end{array}$ & .99 & 4 & .248 & & \\
\hline & $\begin{array}{l}\text { Within } \\
\text { Groups }\end{array}$ & 66.27 & 78 & .850 & & \\
\hline & Total & 67.26 & 82 & & & \\
\hline
\end{tabular}

\section{Conclusions and Recommendations}

A number of conclusions could be drawn from the present study. First of all, it is important for teachers to assess their performance in the class room. To ask themselves whether they need to change their techniques, relationship with students, ways of assessment, reinforcement, comments,... etc. As it is time for teachers to start doing research for themselves instead of leaving the others to dictate them. In the same vein Meek (cited in Brown, 2001:431) stated that:

"The main thing wrong with the world of education is that there's this one group of people who do it- the teachers- and then there's another group who think they know about itthe researchers. The group who think they know about teaching try to find out more about it in order to tell the teachers about teaching- and that is total reversal. Teachers are the ones who do it and, therefore, are the ones who know about it."

Secondly, it is well- known that students play a potential role in the process of teaching, so it is worthy to consider their opinions about the implementation of the class room management components by their teachers. Since they could display a clear image about what is really going on inside the classroom and this could be of a great help for both the teachers and the teaching institution. This effort must begin with a new paradigm in which teachers view classroom management as an ongoing exercise in building relationships. Since in the area of classroom management, it is critical that teachers find ways of building relationships with all students, from the most motivated to the most difficult. (Beaty-O'Ferrall; Green, Alan \& Hanna, Fred, 2010:11).

Thirdly, the results showed that there were no significant differences between students' responses to the questionnaire statements for teachers' assessment that could be attributed to the difference in gender nor to the difference in the academic major of the students who cooperated in this study. This finding could be evidence on the credibility of the subjects' of the study and that they have the same attitudes towards their teachers mindless their gender, or major. Thus their assessment is not affected by those factors and this of course gives unbiased judgment.

The researcher recommended that the stakeholders in educational institutions and universities should consider assessing to what extent are effective classroom management 
components are implemented since assessment plays a vital role in developing the basic skills for students who are the core stone in the teaching process. The researcher also recommends that faculty members of all specialties should give serious consideration to the views of their students and should encourage them to express their opinions and points of view, to accept their criticism and take their assessment as a method of self improvement as students' opinions are like a mirror that reflects ones actions inside the classroom. Teachers should accept their opinions and assessment in order to improve their performance and avoid the negative points if there were any. As Ingwalson \& Thompson, (2007) stated that all efforts to improve education must focus on the single most important component: the classroom teacher since he/she plays the most important role in the whole process of teaching.

\section{References}

Al-Momani, Mufadi, Allouh, Zuhair \& Al-homran, Mohmad. (2012). Teachers Implementation of Effective Classroom Management from Vocational Education Students' Perspectives. International Journal of Education, 4(3), 137-146. http://dx.doi.org/10.5296/ije.v4i3.1802

Beaty-O'Ferrall, Mary Ellen; Green, Alan \& Hanna, Fred. (2010). Classroom Management Strategies for Difficult Students: Promoting Change through Relationships. Middle School Journal, 41(4), 4-11. Retrieved from www. Amle.org/publications/middle school journal/Articles

Bender, W. L. (2003). Relational discipline: Strategies for In-your-face Students. Boston: Pearson.

Brown, H. D. (2001). Teaching by Principles: An interactive Approach to Language Pedagogy $\left(2^{\text {nd }}\right.$ ed). White Plains, NY: Longman.

Carkin, S. (2005). English for Academic Purposes. In E. Hinkel (Ed.) A Handbook of Research in Second Language Teaching and Learning (pp.85-98). New Jersey: Lawrence Elbaum Associates, Inc.

Decker, D. M., Dona, D. P., \& Christenson, S. L. (2007). Behaviorally at-risk African-American students: The importance of student-teacher relationships for student outcomes. Journal of School Psychology, 45(1), 83-109. http://dx.doi.org/10.1016/j.jsp.2006.09.004

Hall, P. S., \& Hall, N. D. (2003). Building Relationships with Challenging Children. Educational Leadership, 61(1), 60-63.

Ingwalson, G., \& Thompson, J., Jr. (2007). A tale of two first-year teachers: One likely to continue, one likely to drop out. Middle School Journal, 39(2), 43-49.

Marzano, R. J., Marzano, J. S., \& Pickering, D. J. (2003). Classroom management that works. Alexandria, VA: Association for Supervision and Curriculum Development. 
Richards, Jack C., Platt, John \& Platt, Heidi. (1992). Language Teaching and Applied Linguistics. London: Longman.

Rogers, C.R. (1969). Freedom to Learn. Columbus, Ohio: Merrill.

Rogers, S., \& Renard, L. (1999). Relationship-driven Teaching. Educational Leadership, 57(1), 34-37.

Wang,V.C.X., \& Kania-Gosche, Beth. (2011). Knowledge Dictator or Knowledge Facilitator: A Dichotomy or Spectrum? International Journal of Vocational Education and Training, 19(1), 23-34.

Yi, Fan. (nd). EFL Classroom Management: Creating a Positive Climate for Learning. Retrieved from http://210.33.23.27/jpkc_nbu/daxueyingyu/download/013.pdf

\section{Copyright Disclaimer}

Copyright reserved by the author(s).

This article is an open-access article distributed under the terms and conditions of the Creative Commons Attribution license (http://creativecommons.org/licenses/by/3.0/). 